\title{
Habitat filtering and interspecific competition influence phenological diversity in an assemblage of Neotropical savanna grasses
}

\author{
Desirée M. Ramos • Pedro Diniz • José F. M. Valls
}

Received: 6 May 2013/Accepted: 19 December 2013/Published online: 12 January 2014

(C) Botanical Society of São Paulo 2014

\begin{abstract}
Phenology in plants is closely related to the environmental features of their habitats, which can act as habitat filtering, clustering species with particular adaptations. On the other hand, aggregation of species can lead to competition between them, segregating their niches. We investigated if habitat filtering and interspecific competition influence phenological diversity in an assemblage of grass species in savanna grasslands of central Brazil. We conducted phenological observations, in 15-day intervals, of ten species of savanna grasses. We used circular statistics to ascertain the seasonality of the phenology and null models to estimate the phenological overlap between species. The reproductive period of grasses was seasonal and concentrated in the rainy season, corroborating the habitat filtering hypothesis; however, within the rainy season, the phenological niche overlap between species was less than expected at random. Flowering was more segregated than fruiting and seed dispersal. Although grasses have similar architectural feature and share similar above and underground niche, these results suggest that grasses are under competition pressure and this can result in phenological segregation, allowing coexistence between them.
\end{abstract}

D. M. Ramos - J. F. M. Valls

University of Brasília, Post-Graduate Program of Botany,

Brasília, Brazil

D. M. Ramos $(\bowtie)$. J. F. M. Valls

Embrapa Genetic Resources and Biotechnology Parque Estação

Biológica PqEB, Av. W5-Norte, Caixa Postal 02372, Brasília,

DF CEP 70.770-900, Brazil

e-mail:desibio@gmail.com

P. Diniz

University of Brasília, Post-Graduate Program of Ecology,

Brasília, Brazil
Keywords Grass · Null model · Phenology · Phenological niche $\cdot$ Savanna

\section{Introduction}

Reproduction in plants is closely related to climatic and environmental traits of their habitats (Frankie et al. 1974; van Schaik et al. 1993). In less seasonal environments, such as rainforests, where climatic limitations are minimal (Morellato et al. 2000), phenological patterns are more limited by phylogenetic constraints than by interspecific competition (Staggemeier et al. 2010). On the other hand, extreme environments features, like freezing in alpine environments (Cornwell et al. 2006) and harsh edaphic conditions in serpentine soils (Williamson and Harrison 2002), can act as an habitat filtering leading to a shared ecological tolerances between species from a community (Cornwell et al. 2006; Sargent and Ackerly 2008). In strongly seasonal environments, such as savannas, the climatic seasonality can exerts a strong pressure by acting as an habitat filtering and limiting the reproduction of herbaceous species mostly to the rainy season (Ramirez 2002).

A result of the habitat filtering can be the reduction in species-specific strategies, resulting in a community of species that share similar traits, such as similar reproductive periods (Weiher et al. 1998; Sargent and Ackerly 2008). However, within this optimal period for reproduction in the community, competition (e.g. for water, light, pollination or nutrients) might segregate phenological niches of species, making the coexistence between them possible (Fargione and Tilman 2005; Cornwell et al. 2006; Levine and HilleRisLambers 2009). Temporal reproductive niches may be represented by different phenological phases of the plant (e.g. flowering, fruiting and dispersal), which 
may be subject to different selective pressures (Rathcke and Lacey 1985; Primack 1987).

The reproductive phenology of grasses in savannas, especially the flowering period, appears limited to the rainy season (Monasterio and Sarmiento 1976; Silva and Ataroff 1985, Sarmiento 1992). Grasses stagger in the reproductive season, with some species exploiting the whole reproductive period and others exploiting the beginning, middle or the ending (Silva and Ataroff 1985; Almeida 1995, Sarmiento 1992). Furthermore, in the dry season, the grasses go through a semi-rest phase without vegetative growth (Monasterio and Sarmiento 1976). Thus, in the rainy season they might need a build-up period to store carbohydrates and to vegetative growth (Munhoz and Felfili 2005; Souza et al. 2010) before flowering.

Water is a limited resource in savanna ecosystems, thus the seasonal availability of this resource may act as the main habitat filtering for the evolution of phenological strategies in grasses. Moreover, species may coexist in a community due to present or past competition. In this sense, we tested habitat filtering and interspecific competition to explain the phenological diversity in an assemblage of grasses. We expected that the reproductive period would be seasonally distributed and concentrated during the rainy season (phylogenetic clustering: according to the habitat filtering) and that, within the rainy season, the phenological niche overlap between species would be less than expected at random (phenological dispersion: according to the competition between species). Since grass species may need a vegetative growth before flowering, we might expect that flowering of assemblage will occur mainly at the middle to the ending of the rainy season.

\section{Materials and methods}

\section{Study area}

We conducted the study at the Environmental Protection Area of the São Bartolomeu river, near Sobradinho, Distrito Federal, Brazil $\left(15^{\circ} 40^{\prime} 20^{\prime \prime} \mathrm{S}\right.$ and $\left.47^{\circ} 44^{\prime} 30^{\prime \prime} \mathrm{W}\right)$. We defined an 11.56 ha patch of savanna grassland for this study. The climate is classified as humid tropical (Aw) (Köppen 1948), characterized by two well defined seasons: a rainy summer and a dry winter. The soil presents a water deficit in the surface layers during the dry season (Eiten 1972; Franco 2002). Rainfall during the study period ranged from zero in the driest month (July) to $150 \mathrm{~mm}$ in the wettest month (April). The accumulated rainfall during the study period (January 2009-March 2010) was $1,152 \mathrm{~mm}$ (Fig. 1). Average monthly temperature ranged from 19.33 to $23.1{ }^{\circ} \mathrm{C}$ along this period. The area is located at an altitude of $1,200 \mathrm{~m}$.
Reproductive phenology

We studied ten of the most abundant species of perennial grasses in the study area (DR, personal observation), which are common (Amaral et al. 2013) and frequent in savanna grasslands of central Brazil (for relative frequency in grasslands see Munhoz and Felfili 2006). For an accurate identification we collected vouchers of the species: Andropogon selloanus (Hack.) Hack., Axonopus pellitus (Nees) Hitchc. and Chase, Axonopus pressus (Nees) Parodi, Echinolaena inflexa (Poir.) Chase, Panicum olyroides Kunth, Paspalum carinatum Humb. and Bonpl. ex Flüggé, Paspalum gardnerianum Nees, Schizachyrium tenerum Nees, Trachypogon spicatus (L.f.) Kuntze, Trichanthecium cyanescens (Nees ex Trinius) Zuloaga and Morrone. We deposited these vouchers in the Herbarium of Embrapa Genetic Resources and Biotechnology (CEN), headquartered in Brasilia.

We measured the phenology of grass species at 15-day intervals from January 2009 to January 2010 (Andropogon selloanus, A. pellitus, Axonopus pressus, Paspalum carinatum, $P$. gardnerianum, Panicum olyroides, Schizachyrium tenerum and Trichanthecium cyanescens), and from March 2009 to March 2010 (Echinolaena inflexa and Trachypogon spicatus). For tree species in tropical forests, this interval of observations provides accuracy and efficiency, regardless of sample size (Morellato et al. 2010a), and has been used for herbaceous layer in savannas of central Brazil (Tannus et al. 2006; Munhoz and Felfili 2007). We estimated that a 15-day interval would provide similar accuracy and efficiency for components of the herbaceous vegetation.

In the field, at the Environmental Protection Area of the São Bartolomeu river, we unsystematically delimited ten individuals of each species. For eight species (Andropogon selloanus, Axonopus pellitus, A. pressus, Paspalum carinatum, $P$. gardnerianum, Panicum olyroides, Schizachyrium tenerum and Trachypogon spicatus), individuals could be clearly delimited. We considered an individual as a set of culms that formed a natural tussock, spatially isolated from other tussocks. For Echinolaena inflexa and Trachypogon cyanescens, species with strong rhizomatous growth, not structured in tussocks, each of the ten individuals corresponded to an area of $100 \mathrm{~cm}^{2}$ delimited within a solid cover matrix of this species. To avoid scoring the same individuals twice, since grasses have vegetative reproduction via rhizomes (Gibson 2009), we chose individuals distant from each other by at least three meters (see Munhoz and Felfili 2005).

We divided the reproduction into three phases: flowering, fruiting and seed dispersal (Zadoks et al. 1974; Tottman et al. 1979). To measure the magnitude of each reproductive phenophase, we used a direct method of quantitatively counting the total number of culms (all 
Fig. 1 Climatic and environmental variables of the study area for the years 2009 and 2010. A the solid line refers to total solar radiation and the dashed line is the average humidity accumulated. B the bars refer to total precipitation accumulated and the line shows the average monthly temperature. $160 \times 240 \mathrm{~mm}$ $(300 \times 300$ DPI $)$
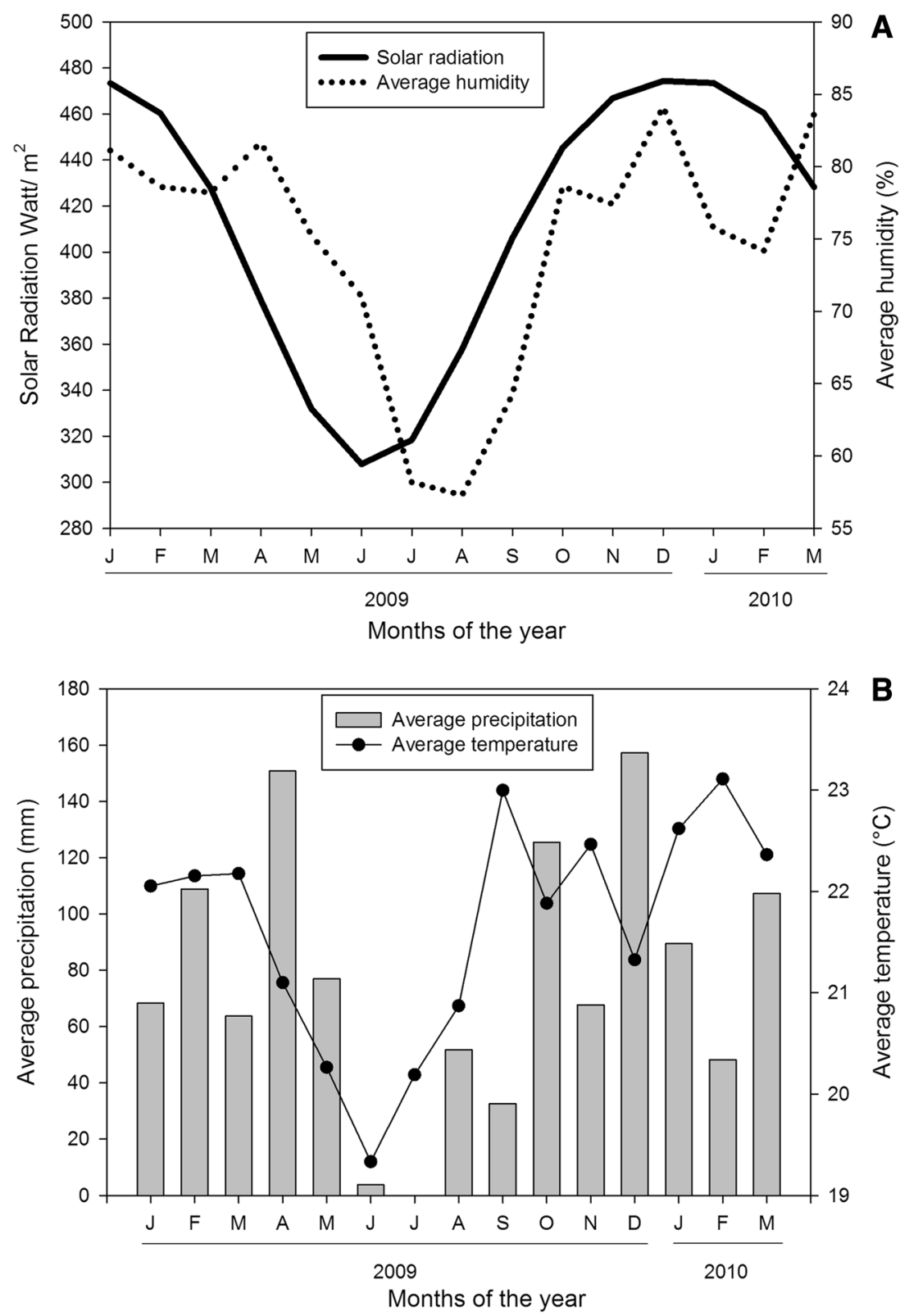

shoots per individual), which were marked with a small wire and recorded concerning the specific plant stages (D'Eça-Neves and Morellato 2004; Morellato et al. 2010a). For each observation we recorded the marked culms and marked the new ones that emerged. This method requires intensive sampling effort and observations are time-consuming, but it allows us to calculate the intensity of phenophases (D'Eça-Neves and Morellato 2004; Morellato et al. 2010a). We considered flowering when the spikelets were in pre-anthesis (closed) or in anthesis (open). We considered as flowering the stages of booting until anthesis according to Zadoks et al. (1974). We considered fruiting when the anthers and stigma fell but the spikelets remained in the rachis, the stages of milk development until ripening also according to Zadoks et al. (1974). We considered dispersal when most (70\% or more) of the spikelets fell from the rachis during or before counting; that is, when the rachis were empty. Grasses commonly present flowering, fruit formation and seed dispersal of spikelets of the same culm at overlapping times; for this reason, we considered, for each observation (i.e. in each 15-day interval), only the dominant phenophase in the respective inflorescence.

Data analysis

\section{Phenological patterns}

We used circular statistics to describe the grass phenological patterns, as in Morellato et al. (2010b). First, we converted the dates of occurrence of a given phenophase 
(e.g. flowering) to angles. We determined the angles for each species, since the collection dates varied among species. We then calculated the average (a) and angular deviation (AD), confidence intervals and length of the vector $r$, for the variables duration of phenophase and early phenophase in populations and communities (groups) of grasses studied. The length of the vector $r$ makes it possible to measure the concentration of a phenophase around the mean angle. The Rayleigh test (Z) (Zar 1999) was used to evaluate the uniformity of phenological data and is useful in determining the degree of seasonality of a phenophase (Morellato et al. 2010b; Talora and Morellato 2000). We made all analyses on circular Oriana software version 3.13.

\section{Phenological niche overlap}

We made analyses of niche overlap with null models to test the hypotheses of habitat filtering and interspecific competition in determining phenological strategies of grasses in the assemblage. For this, we considered the grass use of time for flowering, fruiting and dispersal. We used Pianka's (1973) index of niche overlap to contrast the expected pattern with the observed pattern in the overlap:

$O_{12}=O_{21}=\frac{\sum_{i=1}^{n} p_{2 i} p_{1 i}}{\sqrt{\sum_{i=1}^{n}\left(p_{2 i}^{2}\right)\left(p_{1 i}^{2}\right)}}$

where 1 and 2 represent the pair of species, $p_{i}$ is the proportion of time used $i$ by a species, and $n$ is the total number of 15-day intervals $i$ in a year (24).

We generated ten thousand randomizations to measure the index of overlap expected by chance (null model). To test the hypothesis of habitat filtering, we used the RA3 algorithm (Winemiller and Pianka 1990), which assumes that: (1) the unused resources (15-day intervals of the year without phenophase) are available to the grasses and (2) the breadth of a niche is fixed. Since the reproductive period should be continuous, i.e. the beginning of the reproduction season predicts the use of resources for the dispersal of propagules, we only used the 15-day interval in which the species started its flowering in this stage.

For the hypothesis of interspecific competition, both calculations of niche overlap, observed and expected, followed the RA2 algorithm (Winemiller and Pianka 1990), assuming that: (1) the unused resources (15-day intervals of the year without the phenophase) are inaccessible to the grasses, even in the absence of competition and (2) niche breadth is not fixed, i.e. the intensity of a phenophase can be distributed in any way within the period in which this phenophase is recorded. Thus, considering that the equiprobability of availability (or quality) of resources is not real for a seasonal environment, we defined different weights for the availability of resources in all phenological phases, except the dispersal of propagules phase. We defined the weights of resources based on an index of election (Lawlor 1980):

$e_{i j}=p_{i j} / R_{j}$

where $R$ is a measure of the availability of the resource $j$ in time $i$. We calculated the value of $p_{i j}$ as the average for the assemblage. For the ratio of time use $i$ for each species. We measured $R_{j}$ indirectly from the resources (1) radiation, (2) precipitation, (3) average air humidity and (4) temperature: all are major factors that have shown to be decisive in the growth and reproduction of plants (van Schaik et al. 1993; Wright and van Schaik 1994; Fenner 1998). We summarized these four resources into one eigenvector generated by a principal component analysis (PCA) which explained respectively $76.69 \%$ (PCA1) of original data variance. However, we assumed equiprobable resource use for phase dispersal of propagules, since this seems to have no direct relationship with the availability of energy resources, but with favorable environmental conditions for dispersal (Howe and Smallwood 1982; Batalha and Martins 2004).

\section{Results}

In the scale of assembly, the reproductive period of grasses was seasonally distributed (Rayleigh $Z=13.7, P<0.001$ ). The concentration of reproductive activity was on March 5, in the rainy season. The reproductive peak was not very accentuated ( $r=0.31$, Table 1). The flowering period was concentrated on February 7, still in the rainy season (Table 1), and was more pronounced $(r=0.55)$ than the peak of the reproductive period (Fig. 2). Flowering was highly synchronous, or seasonal (Rayleigh $Z=28.66$, $P<0.001$, Table 1). The fruiting period was concentrated on March 19 (Table 1). The fruiting phenophase was less synchronous and less concentrated $(r=0.33$, Rayleigh $Z=12.52, P<0.001$, Table 1$)$. The peak of dispersal was low $(r=0.4)$, but it was the second most synchronous phenophase (Rayleigh $Z=15.03, P<0.001$, Table 1). The dispersal of seeds of these grasses was concentrated on April 20 (Table 1; Fig. 2), at the end of the rainy season (Fig. 1).

The grasses showed a greater overlap of phenological niches (beginning of the phenophase) than expected by chance for the phenophases fruiting and dispersal, but not for flowering (Table 2). However, considering habitat filtering and the differential quality of the temporal resources, there was segregation of phenological niches of species of grasses for all phenological phases (flowering, fructification, dispersal). Of all the phenological phases, flowering was less overlapped (Table 3), with the species showing a clear segregation of niches in this stage of reproduction. 
Table 1 Reproductive period of grasses in a savanna grassland in Central Brazil

$C I$ confidence interval, $A D$ angular deviation

Rayleigh: $* P<0.05$;

$* * P<0.01 ; * * * P<0.001$

Fig. 2 Circular analysis of the reproductive period, flowering, fructification and dispersal of ten species of grasses in a savanna grassland. The angular mean indicates that reproduction was concentrated in March $(n=141)$, flowering in February (day 9),

fructification in March, and the seed dispersal in April.

$117 \times 115 \mathrm{~mm}$

$(300 \times 300$ DPI $)$

\begin{tabular}{llllll}
\hline & Mean $\pm \mathrm{AD}^{\circ}(n)$ & $95 \% \mathrm{CI}$ & Mean date & Vector $R$ & Rayleigh $(Z)$ \\
\hline Reproduction & $63.09 \pm 87.4^{\circ}(141)$ & $42.2-84.0^{\circ}$ & 05/March & 0.31 & $* * * 13.7$ \\
Flowering & $37.36 \pm 62.2^{\circ}(93)$ & $23.8-50.9^{\circ}$ & 7/February & 0.55 & $* * * 28.66$ \\
Fruiting & $76.38 \pm 85.1^{\circ}(114)$ & $54.6-98.2^{\circ}$ & 19/March & 0.33 & $* * * 12.52$ \\
Seed dispersal & $108.33^{\circ}(92)$ & $88.7-127^{\circ}$ & 20/April & 0.4 & $* * * 15.03$ \\
\hline
\end{tabular}
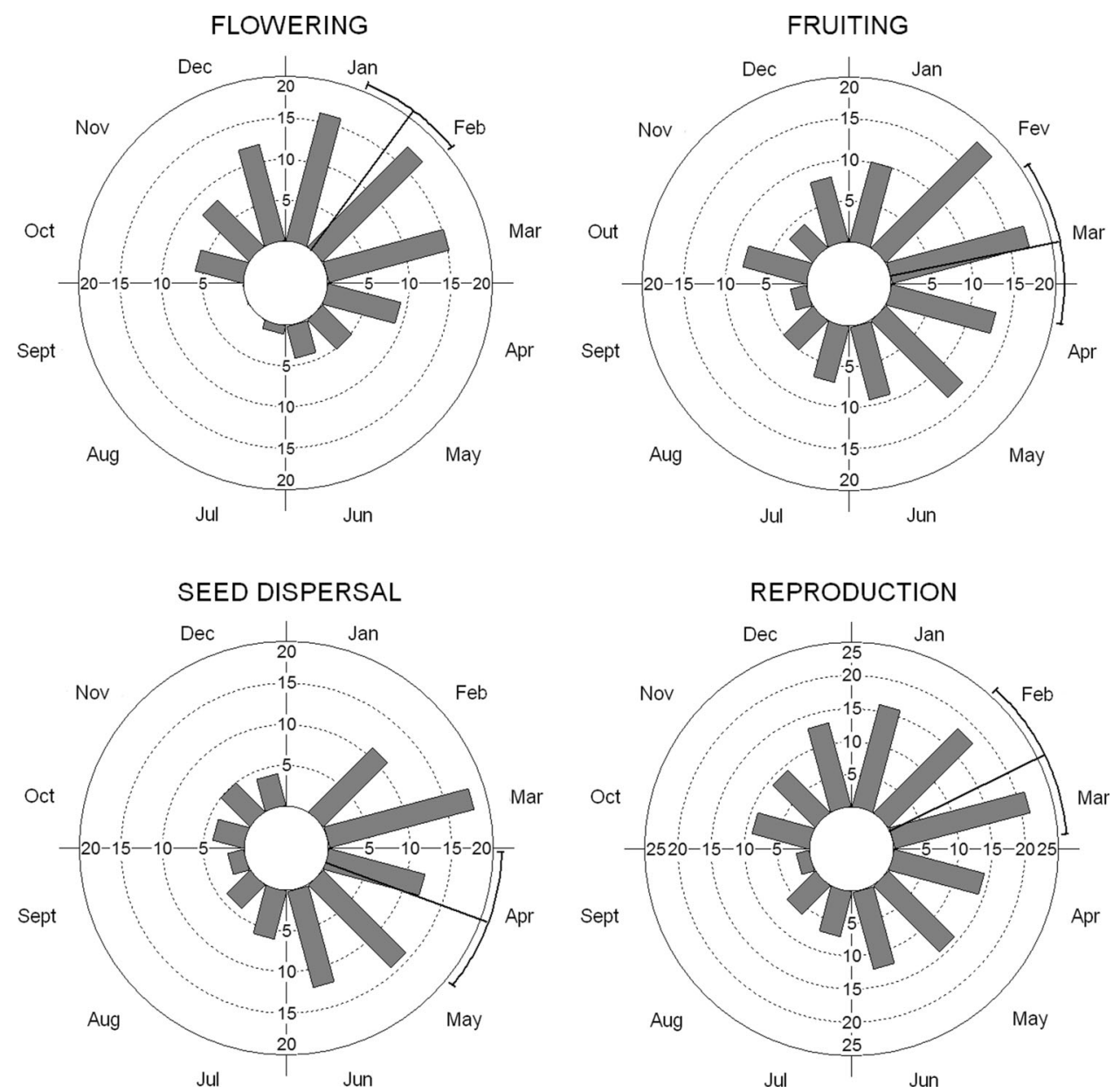

\section{Discussion}

Seasonality of reproduction and habitat filtering

The concentration of the reproductive period of the grasses during the rainy season corroborates the results of previous studies in herbaceous species in Neotropical savannas (Silva and Ataroff 1985; Sarmiento 1992; Batalha and Mantovani 2000; Ramirez 2002; Batalha and Martins 2004; Munhoz and Felfili 2007). The seasonal rainfall was reported by Monasterio and Sarmiento (1976) as the major constraint to the reproduction of plant species in grasslands. In savannas, there is a close link between reproductive period and plant life form, because water availability affects differently woody and herbaceous plants in these environments (Ramirez 2002).

Although grass species flowered during the whole rainy season, flowering was concentrated at the middle of this period (mean date on February 7, Table 1). An explanation for this pattern is that that some species might need a buildup period to accumulates carbohydrates (Souza et al. 2010) for completely vegetative growth and then flowering (Monasterio and Sarmiento 1976; Sarmiento 1992). For instance, the amount of starch in shoots of a Cerrado perennial grass Echinolaena inflexa is lower in the rainy season, when vegetative growth is higher, compared to the dry season, when vegetative growth is lower (Souza et al. 2010). 
Table 2 Niche overlap in the beginning of each phenophase in the reproductive period in a grassland assemblage of grasses in a Neotropical savanna

\begin{tabular}{llll}
\hline Índex of overlap (Pianka) & & \\
\hline & Flowering & Fruiting & Seed dispersal \\
\hline Expected & 0.041 & 0.04 & 0.042 \\
Observed & 0.089 & 0.111 & 0.156 \\
Observed = expected & $P=0.108$ & $P=0.011$ & $P=0.009$ \\
\hline
\end{tabular}

It was assumed a priori that the temporal resources unused by grasses are potentially useful

Table 3 Overlap in reproductive phenology in a grassland assemblage of grasses in a Neotropical savanna

Índex of overlap (Pianka)

\begin{tabular}{llll}
\hline & Flowering & Fruiting & Seed dispersal \\
\hline Expected & 0.474 & 0.431 & 0.409 \\
Observed & 0.360 & 0.331 & 0.349 \\
Observed = expected & $P=0.0001$ & $P=0.0002$ & $P=0.021$ \\
\hline
\end{tabular}

At this stage, it was corrected the unintended effect of habitat filtering, assuming a priori that the temporal unused resources are inaccessible to grasses, but that niche breadth is not fixed

Effect of competition on phenological patterns of the assemblage

The reproductive staggering of herbaceous species, including grasses in savannas (Monasterio and Sarmiento 1976; Silva and Ataroff 1985; Almeida 1995; Madeira and Fernandes 1999), suggests that, although the seasonal drought is a strong habitat filtering that limits reproduction of herbaceous plants to the rainy season, interspecific competition acts as an opposite force to this filter, segregating the reproductive periods of these species.

Tree and shrub species in savannas that have root systems with different depths do not compete with each other for water (Scholes and Archer 1997). However, grass species that have similar roots and coexist in the same habitat may avoid competition by being reproductively active at different times (Golluscio et al. 1998; Martínková et al. 2002; Ogle and Reynolds 2004). The partitioning of resources is an important niche segregating factor in plants (Ashton et al. 2011) that may promote coexistence among species (Jung et al. 2010). Likewise, rhizomatous herbaceous species may compete for soil nutrients on substrates of low productivity (Rebele 2000). Finally, species of grasses in wet savannas share the same spatial water uptake niche (Rossatto et al. 2013). Thus, the temporally segregate pattern of flowering present in this study may be a way of avoiding competition of these seasonal resources by these species, as it was found for grasses by Fargione and Tilman (2005).

While segregation indicates competition, clustered flowering suggests facilitation (e.g. by sharing pollinator species) (Staggemeier et al. 2010). The architecture of grass inflorescence seems to be adapted for wind pollination (Friedman and Harder 2004; Cresswell et al. 2010). Besides the wind, insects have been recorded on grass flowers in tropical forests (Soderstrom and Calderón 1971) and grasslands in Kenya (Bogdan 1962), but our results indicate that there is no trend towards sharing biotic pollinators among these species of grasses. On the contrary, they suggest that there is a competition for other resources during the flowering phenophase. Stigmatic surfaces can be a limited resource and the arrival of heterospecific pollen to these surfaces reduces the availability of space to conspecific pollen, leading to a reduction in seed set (Brown and Mitchell 2001; Arceo-Gómez and Ashman 2011). Segregating the flowering period may be a way to avoid the heterospecific pollen in this assemblage of savanna grasses.

While the flowering of the species follows a pattern clearly segregated for the entire duration of this phenophase, the same was not true for the onset of fruiting and dispersal of diaspores. The less segregated pattern in the seed dispersal phenophase and the overlap in the beginning of fruiting and seed dispersal may indicate a little but important antipredator strategy because mast fruiting and seeding may reduce seed predation by, for instance, having a satiate effect on the predator (Kelly and Sork 2002; Espelta et al. 2008), or by diluting the risk of predation (Hamilton 1971; Augspurger 1983). In the deserts of Argentina, for example, granivory is responsible for the loss of most grass seeds in the soil (Marone and Horno 1997; Marone et al. 1998; Marone et al. 2000), at a rate of up to $50 \%$ (de Casenave et al. 1998; Marone et al. 2000), considering that small mammals and birds are the main seed predators in these deserts (de Casenave et al. 1998). Since, in the savanna, there is a large diversity of granivorous birds (Sick 1997; Bagno and Marinho-Filho 2001; Sigrist 2006; Braz 2008), granivory may be a strong pressure on fruiting and dispersal of diaspores in plants and it constitutes an important environmental filter in these environments. Seed predation is a clear demographic signal for savanna tree species, and the exclusion of seed predators results in high rates of seedling establishment (Vaz Ferreira et al. 2011).

Our findings suggest that drought can be a strong habitat filtering for grass reproduction in savannas by constraining the reproductive period, mainly in the flowering phase, to the middle of the rainy season. Although we did not test the main causes of competition, our results show that competition for resources between grasses can lead to a diversity of phenological strategies as reflected by interspecific phenological niche segregation. 
Acknowledgments We thank CAPES and CNPq, Brazil, for scholarships granted to the first two authors. The third author holds a Research Productivity Grant from CNPq. We also thank the Post-graduate Program of Botany from the University of Brasilia and Embrapa Genetic Resources and Biotechnology for the logistic support for this research. We also thank to Marco A. P. L. Batalha and Fabian Borghetti for the useful comments to the previous version of this manuscript and to the anonymous reviewers of Brazilian Journal of Botany.

\section{References}

Almeida SP (1995) Grupos fenológicos da comunidade de gramíneas perenes de um campo cerrado no Distrito Federal, Brasil. Pesqui Agropecu Bras 30:1067-1073

Amaral AG, Munhoz CBR, Eugênio CUO, Felfili JM (2013) Vascular flora in dry-shrub and wet grassland Cerrado seven years after a fire, Federal District, Brazil. Check List (São Paulo Online) 9:487-503

Arceo-Gómez G, Ashman T (2011) Heterospecific pollen deposition: does diversity alter the consequences? New Phytol 192:738-746

Ashton IW, Miller AE, Bowman WD, Suding KN (2011) Niche complementarity due to plasticity in resource use: plant partitioning of chemical $\mathrm{N}$ forms. Ecology 91:3252-3260

Augspurger CK (1983) Flowering synchrony, and fruit set of six neotropical shrubs. Biotropica 15:257-267

Bagno MA, Marinho-Filho J (2001) A avifauna do Distrito Federal: uso de ambientes abertos e florestais e ameaças. In: Ribeiro JF, Fonseca CEL, Souza-Silva JC (eds) Cerrado - Caracterização e Recuperação de Matas de Galeria. EMBRAPA, Planaltina

Batalha MA, Mantovani W (2000) Reproductive phenological patterns of Cerrado plant species at the Pé-de-Gigante reserve (Santa Rita do Passa Quatro, SP, Brazil): a comparison between the herbaceous and woody floras. Rev Bras Biol 60:129-145

Batalha MA, Martins FR (2004) Reproductive phenology of the Cerrado plant community in Emas National Park (central Brazil). Aust J Bot 52:149-161

Bogdan AV (1962) Grass pollination by bees in Kenya. Proc Linn Soc Lond 173:57-173

Braz V (2008) Ecologia e conservação das aves campestres do bioma Cerrado. Tese de Doutorado, Programa de Pós-Graduação em Ecologia, Instituto de Ciências Biológicas, Universidade de Brasília, Brasília

Brown B, Mitchell R (2001) Competition for pollination: effects of pollen of an invasive plant on seed set of a native congener. Oecologia 129:43-49

Cornwell WK, Schwilk DW, Ackerly DD (2006) A trait-based test for habitat filtering: convex hull volume. Ecology 87:1465-1471

Cresswell JE, Krick J, Patrick MA, Lahoubi M (2010) The aerodynamics and efficiency of wind pollination in grasses. Funct Ecol 24:706-713

D’Eça-Neves FF, Morellato LPC (2004) Métodos de amostragem e avaliação utilizados em estudos fenológicos de florestas tropicais. Acta Bot Bras 18:99-108

de Casenave JL, Cueto VR, Marone L (1998) Granivory in the Monte Desert, Argentina: Is it less intense than in other arid zones of the World? Glob Ecol Biogeogr 7:97-204

Eiten G (1972) The Cerrado vegetation of Brazil. Bot Rev 38:201-341

Espelta JM, Cortés P, Molowwny-Horas R, Sánchez-Humanes B, Retana J (2008) Masting mediated by summer drought reduces acorn predation in Mediterranean oak forests. Ecology 89:805-817

Fargione J, Tilman D (2005) Niche differences in phenology and rooting depth promote coexistence with a dominant $\mathrm{C} 4$ bunchgrass. Oecologia 143:598-606
Fenner M (1998) The phenology of growth and reproduction in plants. Perspect Plant Ecol 1:78-91

Franco A (2002) Ecophysiology of woody plants. In: Oliveira PS, Marquis RJ (eds) The Cerrados of Brazil: ecology and natural history of a Neotropical Savanna. Columbia University Press, Washington, pp 178-197

Frankie GW, Baker HG, Opler PA (1974) Comparative phenological studies of trees in tropical wet and dry forests in the lowlands of Costa Rica. J Ecol 62:881-919

Friedman J, Harder LD (2004) Inflorescence architecture and wind pollination in six grass species. Funct Ecol 18:851-860

Gibson DJ (2009) Grasses and grassland ecology. Oxford University Press, Oxford

Golluscio RA, Sala OE, Lauenroth WK (1998) Differential use of large summer rainfall events by shrubs and grasses: a manipulative experiment in the Patagonian Steppe. Oecologia 115(1/2):17-25

Hamilton WD (1971) Geometry for the selfish herd. J Theor Biol 31:295-311

Howe HF, Smallwood J (1982) Ecology of seed dispersal. Annu Rev Ecol Syst 13:201-228

Jung V, Violle C, Mondy C, Hoffmann L, Muller S (2010) Intraspecific variability and trait-based community assembly. J Ecol 98:1134-1140

Kelly D, Sork VL (2002) Mast seeding in perennial plants: why, how, where? Annu Rev Ecol Syst 33:427-447

Köppen W (1948) Climatologia: con un estudio de los climas de la Tierra. Fondo de Cultura Econômica, México

Lawlor LR (1980) Structure and stability in natural and randomly constructed competitive communities. Am Nat 116:394-408

Levine JM, HilleRisLambers J (2009) The importance of niches for the maintenance of species diversity. Nature 461:254-257

Madeira JA, Fernandes GW (1999) Reproductive phenology of sympatric taxa of Chamaecrista (Leguminosae) in Serra do Cipó, Brazil. J Trop Ecol 15:463-479

Marone L, Horno ME (1997) Seed reserves in the central Monte Desert, Argentina: implications for granivory. J Arid Environ 36:661-670

Marone L, Rossi BE, de Casenave JL (1998) Granivore impact on soil-seed reserves in the central Monte desert, Argentina. Funct Ecol 12:640-645

Marone L, Horno ME, Del Solar RG (2000) Post-dispersal fate of seeds in the Monte desert of Argentina: patterns of germination in successive wet and dry years. J Ecol 88:940-949

Martínková J, Smilauer P, Mihulka S (2002) Phenological pattern of grassland species: relation to the ecological and morphological traits. Flora 197:290-302

Monasterio M, Sarmiento G (1976) Phenological strategies of plant species in the tropical savanna and semi-deciduous forest of the Venezuelan Llanos. J Biogeogr 3:325-356

Morellato LPC, Talora DC, Takahasi A, Bencke CC, Romera EC, Zipparro VB (2000) Phenology of Atlantic rain forest trees: a comparative study. Biotropica 32:811-823

Morellato LPC, Camargo MGG, D'Eça Neves FF, Luize BG, Mantovani A, Hudson IL (2010a) The influence of sampling method, sample size, and frequency of observations on plant phenological patterns and interpretation in tropical forest trees. In: Hudson IL, Keatley M (Org) Phenological research: methods for environmental and climate change analysis. Springer, New York, pp 99-121

Morellato LPC, Alberti LF, Hudson IL (2010b) Applications of circular statistics in plant phenology: a case studies approach. In: Hudson IL, Keatley M (Org) Phenological research: methods for environmental and climate change analysis. Springer, New York, pp 339-359

Munhoz CBR, Felfili JM (2005) Fenologia do estrato herbáceosubarbustivo de uma comunidade de campo sujo na Fazenda 
Água Limpa no Distrito Federal, Brasil. Acta Bot Bras 19:981-990

Munhoz CBR, Felfili JM (2006) Fitossociologia do estrato herbáceosubarbustivo de uma área de campo sujo no Distrito Federal, Brazil. Acta Bot Bras 20:671-685

Munhoz CBR, Felfili JM (2007) Reproductive phenology of an herbaceous-subshrub layer of a Savannah (Campo Sujo) in the Cerrado Biosphere Reserve I, Brazil. Braz J Biol 67:299-307

Ogle K, Reynolds JF (2004) Plant responses to precipitation in desert ecosystems: integrating functional types, pulses, thresholds, and delays. Oecologia 141:282-294

Pianka ER (1973) The structure of lizard communities. Annu Rev Ecol Syst 4:53-74

Primack RB (1987) Relationships among flowers, fruits, and seeds. Annu Rev Ecol Syst 18:409-430

Ramirez N (2002) Reproductive phenology, life-forms, and habitats of the Venezuelan Central Plain. Am J Bot 89:836-842

Rathcke B, Lacey EP (1985) Phenological patterns of terrestrial plants. Annu Rev Ecol Syst 16:179-214

Rebele F (2000) Competition and coexistence of rhizomatous perennial plants along a nutrient gradient. Plant Ecol 147:77-94

Rossatto DR, Sternberg LSLO, Franco AC (2013) The partitioning of water uptake between growth forms in a Neotropical savanna: do herbs exploit a third water source niche? Plant Biol 15:84-92

Sargent RD, Ackerly DD (2008) Plant-pollinator interactions and the assembly of plant communities. Trends Ecol Evol 23:123-130

Sarmiento G (1992) Adaptive strategies of perennial grasses strategies in South American Savannas. J Veg Sci 3:325-336

Scholes RJ, Archer SR (1997) Tree-grass interactions in savannas. Annu Rev Ecol Syst 28:517-544

Sick H (1997) Ornitologia Brasileira. Nova Fronteira, Rio de Janeiro Sigrist T (2006) Aves do Brasil: uma visão artística. AvisBrasilis, São Paulo

Silva JF, Ataroff M (1985) Phenology, seed crop and germination of coexisting grass species from a tropical savanna in western Venezuela. Acta Oecol Oec Plant 6:41-51

Soderstrom TR, Calderón CE (1971) Insect pollination in tropical rain forest grasses. Biotropica 3:1-16
Souza A, Sandrin CZ, Meirelles ST, Pivello VR, Figueiredo-Ribeiro RCL (2010) Seasonal variation of soluble carbohydrates and starch in Echinolaena inflexa, a native grass species from the Brazilian savanna, and the invasive grass Melinis minutiflora. Braz J Biol 70:631-637

Staggemeier VG, Diniz-Filho JAF, Morellato LPC (2010) The shared influence of phylogeny and ecology on the reproductive patterns of Myrteae (Myrtaceae). J Ecol 98:1409-1421

Talora DC, Morellato PC (2000) Fenologia de espécies de arbóreas em floresta de planície litorânea do sudeste do Brasil. Rev Bras Bot 23:13-26

Tannus JLS, Assis MA, Morellato LPC (2006) Fenologia reprodutiva em campo sujo e campo úmido numa área de cerrado no sudeste do Brasil, Itirapina-SP. Biota Neotrop 6:1-27

Tottman DR, Makepeace RJ, Broad H (1979) An explanation of the decimal code for the growth stages of cereals, with illustrations. Ann Appl Biol 93:221-234

van Schaik CP, Terborgh JW, Wright S (1993) The phenology of tropical forests: adaptive significance and consequences for primary consumers. Annu Rev Ecol Syst 24:353-377

Vaz Ferreira A, Bruna EM, Vasconcelos HL (2011) Seed predators limit plant recruitment in Neotropical savannas. Oikos 120:1013-1022

Weiher E, Clarke GDP, Keddy PA (1998) Community assembly rules, morphological dispersion, and the coexistence of plant species. Oikos 81:309-322

Williamson J, Harrison S (2002) Biotic and abiotic limits to the spread of exotic revegetation species. Ecol Appl 12(1):40-51

Winemiller KO, Pianka ER (1990) Organization in natural assemblages of desert lizards and tropical fishes. Ecol Monogr 60:27-55

Wright SJ, van Schaik CP (1994) Light and the phenology of tropical trees. Am Nat 143:192-199

Zadoks JC, Chang TT, Konzak CF (1974) A decimal code for the growth stages of cereals. Weed Res 14:415-421

Zar JH (1999) Biostatistical analysis. Prentice Hall, Upper Saddle River 